\title{
Study of serum lipase level in pregnant woman presenting with nausea and vomiting
}

\author{
Arun Dhungana ${ }^{1}$, Pratigyan Gautam² ${ }^{2}$ Rosina Manandhar ${ }^{2}$, Chanda Karki ${ }^{2}$ \\ ${ }^{1}$ Department of Biochemistry, Kathmandu Medical College, Kathmandu, Nepal. \\ ${ }^{2}$ Department of Obstetrics and Gynaecology, Kathmandu Medical College, Kathmandu, Nepal.
}

\section{Keywords: \\ Acetone; \\ Amylase; \\ Gravidarum; \\ Hyperemesis; \\ Lipase;}

\begin{abstract}
Background: Hyperemesis gravidarum is a complex condition characterized by excessive nausea and vomiting during pregnancy. It presents with various symptoms which include disturbed nutrition, electrolyte imbalance, ketosis and extreme weight loss. The objective of this study is to compare serum lipase, amylase and glucose in Hyperemesis gravidarum with non-pregnant women.

Materials and methods: A total of 100 subjects among which 50 were nonpregnant women as controls and 50 were women with hyperemesis gravidarum as cases were enrolled in the study. Serum lipase, amylase and glucose levels were estimated in all the subjects.

Results: The levels of mean serum lipase were lesser in cases $(23.55 \pm 4.91 \mathrm{U} / \mathrm{L})$ compared to that in controls $(25.45 \pm 5.97 \mathrm{U} / \mathrm{L})$ with $\mathrm{p}=0.086$. However, the levels of mean serum amylase were higher in cases $(76.40 \pm 33.86 \mathrm{U} / \mathrm{L})$ compared to that in controls $(69.66 \pm 16.45 \mathrm{U} / \mathrm{L})$ with $\mathrm{p}=0.210$. Serum amylase activity was raised in $8 \%$ of the patients whereas the activity of pancreatic lipase was within normal range. Serum glucose levels were lower in cases $(84.72 \pm 11.28 \mathrm{mg} / \mathrm{dl})$ than that in controls $(87.04 \pm$ $10.65 \mathrm{mg} / \mathrm{dl}$ ) with $\mathrm{p}=0.293$.

Conclusion: From this study we conclude that lipase activity was statistically insignificant in hyperemesis gravidarum. Therefore, pancreatic activities were less affected by hyperemesis gravidarum. So, this condition needs further exploration regarding biochemical basis to minimize the risk associated with it.
\end{abstract}

\section{Correspondence:}

Dr. Arun Dhungana

Lecturer, Department of Biochemistry

Kathmandu Medical College Teaching Hospital, Kathmandu, Nepal ORCID ID: 0000-0003-2083-649X

Email:a_dhungana1@yahoo.com

Received : December 14 $4^{\text {th }} 2018$; Accepted : March 20 2019; Published : March $29^{\text {th }} 2019$

Citation: Dhungana A, Gautam P, Manandhar R, Karki C. Study of serum lipase level in pregnant woman presenting with nausea and vomiting. J Pathol Nep 2019;9:1480-4. DOI: 10.3126/jpn. v9i1.23374

Copyright: This is an open-access article distributed under the terms of the Creative Commons Attribution 4.0 International License, which permits unrestricted use, distribution, and reproduction in any medium, provided the original author and source are credited.

\section{INTRODUCTION}

Human lipase (LPS) is also known as triacylglycerol acylhydrolase a single-chain glycoprotein with a molecular weight of 48,000 and an isoelectric point of about 5.8. Lipases are defined as enzymes that hydrolyze glycerol esters of long-chain fatty acids. ${ }^{1}$ Gastric function status during pregnancy can be adequately assessed by the levels of serum amylase and lipase. ${ }^{2}$ Serum amylase and lipase levels have been reported to rise in the patients with hyperemesis gravidarum. ${ }^{3,4}$ Hyperemesis gravidarum (HG) or early gestosisis characterized by excessive nausea as well as early pregnancy related vomiting, ${ }^{5}$ but without feelings of 
sickness and impairment to wellbeing. ${ }^{6}$ It is reported to be associated with increased risks for low-birth-weight (LBW), preterm birth (PTB), small-for-gestational-age (SGA) and perinatal death. ${ }^{5}$ Nausea and vomiting are both common medical condition affecting pregnancy and present in up to $85 \%$ of gestations. ${ }^{7-9}$ Symptoms usually begin between 4 and 6 weeks of gestation, peak between 8 and 12 weeks, and resolve by 20 weeks., ${ }^{4,11}$ In approximately $10 \%$ of HG patients, symptoms will persist throughout pregnancy. ${ }^{11}$ It is well known that pregnant women experience physiological changes, which induce modifications in serum protein concentrations and certain enzyme activities. ${ }^{12}$ Even more, acute pancreatitis is diagnosed in the pregnant women who also experience abdominal pain as well as nausea and vomiting mainly on the basis of raised levels of amylase and/or lipase..$^{13} \mathrm{~A}$ limited number of researches have been done to reveal the physiological changes during pregnancy. Hence, this study is an attempt to know whether the gestation stage per se induces modifications in serum amylase and lipase activities or not.

\section{MATERIALS AND METHODS}

The present prospective case control study was carried out at Kathmandu medical college from September 2017 to September 2018. In this present study subjects were categorized into two groups as: group $\mathrm{I}=$ non-pregnant healthy woman and group $\mathrm{II}=$ pregnant women with Hyperemesis gravidarum attending outpatient and inpatient department.

A written consent was taken from the patients to participate in this study and ethical clearance approval was obtained from institutional review committee (IRC). Demographic data regarding age, period of gestation, gravid and weight was taken. Blood sample was obtained from all the participants by venipuncture from cubital vein and sample was collected in a vial under aseptic condition for biochemical analysis. The serum lipase level was estimated with semi-auto analyzer whereas; the levels of serum amylase, glucose were estimated with Selectra pro S auto analyzer using Elitech reagents, and routine urine sample was analyzed both in cases and controls to detect ketone bodies. A total of 100 pregnant women, aged 20 to 35 years were recruited for the study, out of which of 50 were non-pregnant healthy women and 50 were admitted and diagnosed case of Hyperemesis gravidarum. Subjects with history of intake of thyroid drugs, hypertensive, diabetes mellitus, obesity, all other causes for electrolyte abnormalities, renal disorders, malabsorption syndrome, hepatic disorders and pancreatitis, acute intra-abdominal disorders, such as perforated gastric or duodenal ulcer, intestinal obstruction, or mesenteric vascular obstruction 1 were excluded from the study. Subjects on diuretics, not fitting into criteria and any other systemic disease those with other possible abdominal conditions, were also excluded. According to the reference article, by Dambazau et al²:

Mean serum lipase (m1) among pregnant females: 117.22

Standard deviation of serum lipase among pregnant females: 20.52

Mean serum lipase (m1) among non - pregnant females: 120.09

Standard deviation of serum lipase among non - pregnant females: 13.37

$$
\begin{aligned}
& \text { Calculation of Effect size (ES) using formula }=\mathrm{ES}=\frac{\left|\mu_{1}=\mu_{2}\right|}{\sigma} \\
& =2.245
\end{aligned}
$$

Taking level of significance $(\alpha)=5 \%$

Taking power of the study $(1-\beta)=80 \%$

Applying all the values in the following formula for estimation of sample size :

$$
\mathrm{n}_{1}=2\left(\frac{\mathrm{z}_{1}-\alpha / 2^{+\mathrm{z}_{1}} 1-\beta}{\mathrm{ES}}\right)^{2}
$$

The calculated sample size is 523 in each group. In our current study, our inclusion criteria include only those pregnant women who get admitted due to hyperemesis gravidarum. The hospital records showed that around 50 pregnant women get admitted due to it annually.

Putting the values, in the following formula of population finite correction, $\mathrm{N}=50$, no $=523$.

$$
\mathrm{n}=\frac{\mathrm{n}_{0}}{1+\frac{\left(\mathrm{n}_{0}-1\right)}{\mathrm{N}}}
$$

The sample size is 42 . Amplifying the sample size by $10 \%$ for processing errors, the final sample size is $42+4.2=46.2$

Thus, we planned to take 50 samples in both the groups i.e. 50 non-pregnant females and 50 Hyperemesis gravidarum.

\section{Statistical analysis}

Statistical analysis was done by SPSS (Statistical package 
Table 1: Comparison of clinical characteristics for group of participants

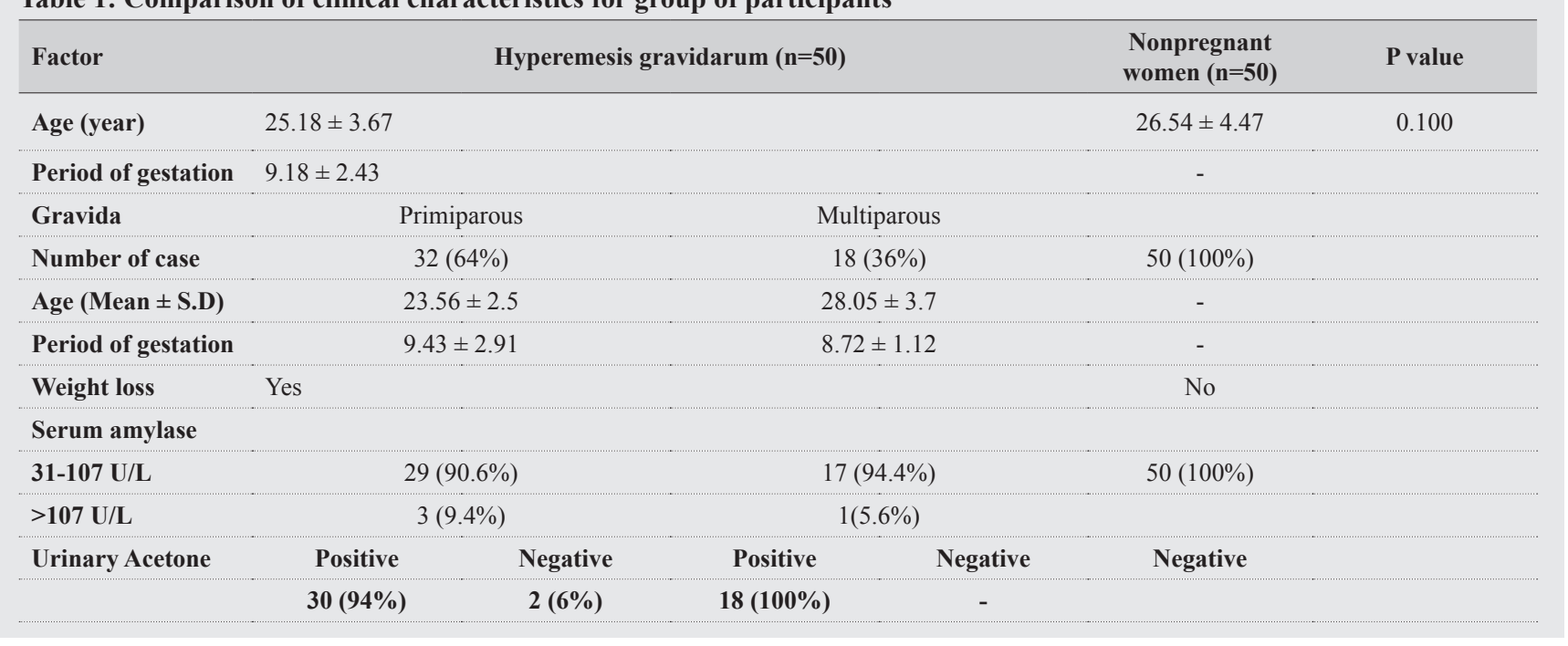

Table 2: Comparison of serum lipase, amylase and glucose for different groups

\begin{tabular}{|c|c|c|c|c|}
\hline Parameter & Diagnosis & Number of patient & Mean \pm SD & P value \\
\hline \multirow{2}{*}{ Serum lipase } & Hyperemesis gravidarum & \multirow{2}{*}{50} & $23.55 \pm 4.91$ & \multirow{2}{*}{0.086} \\
\hline & Nonpregnant women & & $25.45 \pm 5.97$ & \\
\hline \multirow{2}{*}{ Serum amylase } & Hyperemesis gravidarum & \multirow{2}{*}{50} & $76.40 \pm 33.86$ & \multirow{2}{*}{0.210} \\
\hline & Nonpregnant women & & $69.66 \pm 16.45$ & \\
\hline \multirow{2}{*}{ Serum glucose } & Hyperemesis gravidarum & \multirow{2}{*}{50} & $84.72 \pm 11.28$ & \multirow{2}{*}{0.293} \\
\hline & Nonpregnant women & & $87.04 \pm 10.65$ & \\
\hline
\end{tabular}

for social science) version 15. Independent sample t-test was used to compare the means between different groups.

\section{RESULTS}

Comparison of the clinical characteristics and symptoms for group of participants are shown in the table 1. Among the pregnant females $64 \%(n=32)$ of cases were primiparous with mean age of 23.56 years. Most of patients presented with weight loss. Four (8\%) cases had increased amylase activity above the normal upper limit and $6 \%(n=2)$ of cases had negative urinary acetone test. Comparison of serum lipase, amylase and glucose for different groups are shown in table 2. The findings of serum lipase, amylase and glucose were statistically insignificant. ( $p$ value $>0.05$ )

\section{DISCUSSION}

Pregnancy is a unique situation or a period induced by various physiological changes coupled with emotional stress and challenges. It also contributes to changes in hormonal and biochemical status of pregnant women, especially, electrolytes imbalance and depletion of macronutrients. ${ }^{2,14}$ In this prospective case control study, diagnosed cases of hyperemesis gravidarum were compared with nonpregnant healthy women all aged from 20 to 35 years. In the present study the mean serum lipase level of hyperemesis gravidarum
(23.55 $\pm 4.91 \mathrm{U} / \mathrm{L})$ was compared to nonpregnant women $(25.45 \pm 5.97 \mathrm{U} / \mathrm{L})$ which was statistically insignificant $(p=0.086)$ as shown in Table 2 . The primary serum levels of lipase for all the groups were found to be within the normal range which showed that none of the screened groups were at risk of acute pancreatitis. The level of serum lipase was lesser when it was compared to control. A study conducted by Karsenti et $\mathrm{al}^{15}$ observed that the serum lipase activity was decreased during first trimester and mechanism behind this is not known. In this study the level of serum amylase in nonpregnant women $(69.66 \pm 16.45 \mathrm{U} / \mathrm{L})$ when compared to the case of hyperemesis gravidarum $(76.40 \pm 33.86 \mathrm{U} / \mathrm{L})$ was also not statistically significant $(p=0.210)$ as shown in Table 2. A study conducted by Dambazau S.M et $\mathrm{al}^{2}$ for screening serum amylase and lipase status in normal pregnant woman was also statistically insignificant. The serum level of amylase and lipase for all the groups were also found to be within the normal range. In this present study as shown in Table $1.8 \%(n=4)$ of case had raised level of Serum amylase and such rise has been reported in some of the patients with hyperemesis gravidarum, which could be either due to amylase released from the salivary gland and not from the pancreas. ${ }^{16}$ Such repeatedly stimulating the salivary glands, may lead to increased amylase production and enlargement of salivary glands or ingestion of high quantities of carbohydrate-rich food has also been suggested as a cause of raised serum amylase. ${ }^{16,}$ 
${ }^{17}$ A study conducted by Dawes et al ${ }^{17}$ found little evidence that the salivary amylase concentration can be altered by variation of dietary carbohydrate intake. Even though there was a raised total serum amylase activity in $8 \%$ of patient but there was no rise in pancreatic lipase activity. Both the group remained to be within the normal limit, even if lipase has greater specificity. In our study $4 \%(n=2)$ of the case was negative for acetone test this could be due to relation between ketonaemia and ketonuria.

In our study the level of glucose was $(84.72 \pm 11.28 \mathrm{mg} / \mathrm{dL})$ lower in hyperemesis gravidarum when it was compared with $(87.04 \pm 10.65 \mathrm{mg} / \mathrm{dL})$ non pregnant women which was also statistically insignificant $(p=0.293)$. It could be due to low caloric food consumption due to severe nausea and vomiting which could have result to weight loss in hyperemesis gravidarum cases. ${ }^{18,19}$ A Study conducted by Watanabe $\mathrm{S}$ et $\mathrm{a}^{20}$ obtained decreased blood glucose level in fasting state.

This is a case control study which is conducted during the first trimester and due to small sample size we could not standardize the reports; further studies need to be conducted on a larger population of pregnant women with hyperemesis gravidarum and nonpregnant women regarding liver function test, renal function test along with amylase and lipase activity to correlate and to find the relation between the parameter for a clear picture to understand the disease.

\section{CONCLUSION}

Hyperemesis gravidarum is a condition with in addition to deleterious effects on physical and psychological health of mother. The levels of serum lipase activity were at normal level when compared to nonpregnant subjects. Therefore, pancreatic activities were less affected by hyperemesis gravidarum. This disease needs to be further explored, and a major focus should be done on modifiable risk factors and better treatment regimen. With improved therapy hopefully we can reduce the burden for affected women as well as society.

\section{ACKNOWLEDGEMENT}

We would like to thank the participants and nursing team, especial thanks to Asst. Prof. Mr. Arun Pandeya, Lecturer Mr. Naveen Shreevastva, laboratory staff, Mr. Hari Sharan Makaju for the great help and support during the episode of the study.

\section{Conflict Interest: None}

\section{REFERENCES}

1. Burtis CA, Ashwood ER, Bruns DE. Serum enzyme. In: Panteghini M, Bais R, editors. Tietz text book of clinical chemistry and molecular diagnostics. 5th ed. Philadelphia: Elsevier Saunders; 2012. p. 585-7.
2. Dambazau SM, Umar UA, Singh D. Screening of serum amylase and lipase status in pregnant women. Asian Journal of Science and Technology. 2017;8:5720-4. $\underline{\text { Crossref }}$

3. Kuscu NK, Koyuncu F. Hyperemesis gravidarum: current concepts and management. Postgrad Med J. 2002;78:76-9. 당ssref

4. Johnson A, Cluskey B, Hooshvar N, Tice D, Devin C, Kao E, et al. Significantly elevated serum lipase in pregnancy with nausea and vomiting: acute pancreatitis or hyperemesis gravidarum? Case Rep Obstet Gynecol. 2015;2015:359239. Crossref

5. Vikanes AV, Stoer NC, Magnus P, Grjibovski AM. Hyperemesis gravidarum and pregnancy outcomes in the Norwegian Mother and Child Cohort - a cohort study. BMC Pregnancy Childbirth. 2013;13:169. Crossref

6. Mylonas I, Gingelmaier A, Kainer F. Nausea and Vomiting in Pregnancy. Dtsch Arztebl. 2007;104:1-8.

7. Arulkumaran S, Symonds IM, Fowlie A. Hyperemesis Gravidarum. Oxford handbook of Obstetrics and Gynaecology. New Delhi: Oxford university press; 2004. p. 71.

8. Dutta DC. vomiting in pregnancy. In: Konar H, editor. Text book of obstetrics. Chintamoni Das Lane, calcutta: New central book agency; 2004. p. 156.

9. Einarson TR, Piwko C, Koren G. Prevalence of nausea and vomiting of pregnancy in the USA: a meta analysis. J Popul Ther Clin Pharmacol. 2013;20:e163-70. Crossref

10. Verberg MF, Gillott DJ, Al-Fardan N, Grudzinskas JG. Hyperemesis gravidarum, a literature review. Hum Reprod Update. 2005;11:52739. $\underline{\text { Crossref }}$

11. Gadsby R, Barnie-Adshead AM, Jagger C. A prospective study of nausea and vomiting during pregnancy. Br J Gen Pract. 1993;43:2458. Crossref

12. Bacq Y, Zarka O, Brechot JF, et al. Liver function tests in normal pregnancy: a prospective study of 103 pregnant women and 103 matched controls. Hepatology. 1996;23:1030-4. $\underline{\text { Crossref }}$

13. Chen CP, Wang KG, Su TH, Yang YC. Acute pancreatitis in pregnancy. Acta Obstet Gynecol Scand. 1995;74:607-10. Crossref

14. Zavalza-Gomez AB, Anaya-Prado R, Rincon-Sanchez AR, MoraMartinez JM. Adipokines and insulin resistance during pregnancy. Diabetes Res Clin Pract. 2008;80:8-15. Crossref

15. Karsenti D, Bacq Y, Brechot JF, Mariotte N, Vol S, Tichet J. Serum amylase and lipase activities in normal pregnancy: a prospective case-control study. Am J Gastroenterol. 2001;96:697-9. Crossref

16. Robertson C, Millar H. Hyperamylasemia in bulimia nervosa and hyperemesis gravidarum. Int J Eat Disord. 1999;26:223-7. Crossref 
17. Dawes C. Effects of diet on salivary secretion and composition. J Dent Res. 1970;49:1263-73. Crossref

18. Konikoff T, Avraham T, Ophir E, Bornstein J. Hyperemesis gravidarum in northern Israel: a retrospective epidemiological study. Isr J Health Policy Res. 2016;5:39. Crossref

19. Madendag Y, Sahin E, Madendag Col I, et al. The effect of hyperemesis gravidarum on the $75 \mathrm{~g}$ oral glucose tolerance test screening and gestational diabetes mellitus. J Matern Fetal Neonatal Med. 2018;31:1989-92. Crossref
20. Watanabe S, Hirakawa A, Utada I, Aoe S, Moriyama S, Hitomi S, et al. Ketone Body Production and Excretion During Wellness Fasting. Diabetes Res Open J. 2017;3:1-8. Crossref 